\title{
Cultural diplomacy in Qatar: Between 'virtual enlargement', national identity construction and elite legitimation
}

\begin{abstract}
This paper analyses how the government of Qatar has over the last years used practices of cultural diplomacy to enhance its standing abroad, and consolidate its legitimacy at home. Looking in particular at key initiatives of international collaboration of the Qatar Foundation and Qatar Museums, I argue that the Qatari government strategically uses cultural diplomacy to first produce and then disseminate an elite identity narrative of Qatar being a cohesive, future-oriented and rightfully engaged player in international affairs both inside and outside the state. To develop this argument, the analysis builds on observation during fieldwork in Doha between 2015 and 2016, and is enriched by a textual analysis of primary and secondary sources. As a timely contribution, the paper moreover shows that even in the light of considerable economic downturn, where budgets are cut and state-projects downsized, official narratives about Qatar's global cultural ambitions have so far remained largely unchanged.
\end{abstract}

Key Words: Qatar, cultural diplomacy, national identity, virtual enlargement, legitimation

\section{Introduction:}

The state of Qatar has recently started to attract a great amount of international attention. What is striking is that across both academic and popular discourse, virtually every account points to its small size as potentially puzzling. Academic examples include Mehran Kamrava's 'Qatar - Small State, Big Politics' (2013), or J. E. Peterson's 'Qatar and the World: Branding for a Micro-State' (2006). On the popular side, Qatar has been described as a 'bouncy bantam' and a 'pygmy with the punch of a giant' (The Economist 2006, 2011). Across the majority of publications, the phrase looms large that Qatar is 'punching above its weight' in global affairs (Roberts 2011).

In this paper, I reverse the gaze and rather than continue the debate about size as a potential constraint, look at what the political leadership in Doha has actually done to position itself internationally, how and why. Adding to a quickly growing body of literature on Qatar's international engagements (see Barakat 2012; Ulrichsen 2012; Reiche 2014; Exell 2016), I will look in particular at how the Qatari government has 
used the 'field of culture' to influence the world to its advantage (Kluijver 2013). More specifically, I will look at Doha's pursuit of an active cultural diplomacy in the form of cultural exchange programs and bilateral international collaborations of the state's two main cultural organisations, Qatar Museums (QM) and the Qatar Foundation (QF). Throughout, I develop the argument that cultural diplomacy serves a dual purpose in Qatar. On the one hand, it functions as a strategic projection of a positive national image to 'virtually enlarge' the state's international visibility and favourably position it in strategic global networks. On the other hand, it is linked to the production of an elitedriven national identity narrative for domestic consumption. Taken together, cultural diplomacy thus reflects Doha's cosmopolitan assumptions, and its strategic use of references to the international to consolidate a still forming national identity and the political leadership's position within it.

As a timely contribution, the analysis moreover shows that the current economic downturn in the Gulf, triggered by falling oil prices since the summer of 2014 (from around US\$110/barrel in June 2014, to US\$30/barrel at the end of 2015, and US\$52 in December $2016^{1}$ ), has not yet resulted in major shifts in official state narratives about Qatar's national and global ambitions. While the government was restructured and state-owned institutions -including QM and QF- experienced budget cuts, official narratives largely continue as before. At the time of writing, we can however already observe a changing accent in the government's cultural practices as simultaneously becoming more modest and inward-looking.

The research process for this paper started with participation observation during fieldwork in Qatar in 2015 and 2016, and was later enriched by a textual analysis of official documents and public statements. Overall, 153 documents collected in the field,

\footnotetext{
${ }^{1}$ Data retrieved from http://databank.worldbank.org/data/databases/commodity-price-data February 2017.
} 
through standard internet searches and targeted LexisNexis searches were coded and analysed with the help of the qualitative data analysis software NVivo. Importantly, the swirl of change that has characterised the development of Qatar over time does not stop under the watchful eyes of the academic observer. Essentially observing a 'moving target', the following analysis is hence not meant to be read as a claim to complete knowledge, but as an interpretation of the greater political ambitions and implications linked to Doha's promotion of itself as a 'cultural hub'.

To develop and support the above argument, the paper proceeds in two parts. The first part familiarizes the reader with the case of Qatar, discusses the concept of cultural diplomacy, and underlines its importance as simultaneously being part of Doha's outward- and inward-looking policy. The second part then offers an in-depth analysis of a number of key initiatives of international collaboration and exchange of QM and QF that have so far received only little attention in the academic discourse. Finally, a conclusion sums up the findings.

\section{The case of Qatar:}

The State of Qatar emerged on the international stage when it gained independence from Great Britain in 1971. It is located on the eastern shore of the Arabian Peninsula, and has since the $19^{\text {th }}$ century continuously been ruled by the Al Thani tribe in a system of absolute hereditary monarchy. The Al Thani first consolidated their power over the territory that forms modern day Qatar through two treaties with the British in 1868 and 1916 that recognised the tribe as the primary local authority (cooke 2015; Fromherz 2012). To underline the rightfulness of this position, Fromherz (2012) argues, 'the current regime is [to this day] going through incredible lengths to re-write the history of the state focusing on Al Thani lineage as the key to Qatar's existence' (154). This is important, as control of the state has over the course of the $20^{\text {th }}$ century developed into 
control over enormous natural resource reserves. Fuelled by its oil and gas wealth, Qatar has over the last decades transformed from a 'poor backwater and practical vassal of Saudi Arabia [...into] one of the region's richest, most recognizable and highly influential states' [sic] (Kamrava 2013, 3).

The fast pace of change has become most visible in the development of Qatar's capital city Doha. Little more than an inhospitable fishing village well into the 1930s, Doha today is 'obsessed with its image as a modern city' that simultaneously 'remains mindful of its past' (Kamrava 2013, 8). Covering a territory of approximately $11,5 \mathrm{~km}^{2}$, Qatar ranks $166^{\text {th }}$ out of 257 countries worldwide in terms of landmass, and is the second smallest Gulf state, followed only by Bahrain $\left(760 \mathrm{~km}^{2}\right)$ (CIA Factbook 2016). According to the Ministry of Development Planning and Statistics, Qatar was home to 2,5 million residents in December 2016, with a population increase of almost 2 million over the last 15 years. Of these 2,5 million, however, only around 250,000 - 300,000 are Qatari nationals (Winckler 2015) ${ }^{2}$. Attracted by its economic rise, the majority of Qatar's residents are migrant workers from South Asia, who work in the state's burgeoning construction- and service industries. These numbers make Qatar not only a small state in terms of population and territory, but also leave the Qataris themselves as a minority in their own country.

According to Exell (2016a), these two factors, rapid economic development and the changing face of Qatari society on the one hand, and the outnumbering of Qatari nationals by migrant workers on the other hand, characterise the very particular socioeconomic context of Qatar. Within this context, she argues, the Qatari government has been eager to develop a tightly-knit identity narrative 'in which a carefully selected past

\footnotetext{
${ }^{2}$ There are no exact public records on the exact number of Qatari citizens. According to Winckler (2015), the total number is considered a 'national secret' due to the state's sensitive social contract based on the distribution of rentier wealth, and various waves of citizen naturalization.
} 
supports a pure 'Qatari' present and future' as a means to establish national coherence, unity and pride (2016a). This is necessary, as enormous wealth has transformed traditional life on the peninsula at such unprecedented speed that a single generation separates two distinct lifestyles, 'resulting in feelings of anxiety and a desire for preservation of 'the past' on the part of the older generation and a lack of knowledge of this earlier lifestyle on part of the younger generation' (Exell and Rico 2013, 676). To counter these feelings, the political leadership in Doha has (re)invented a civic myth about Qatar's heritage, traditions and culture (Kamrava 2013; Levitt 2015). Over the years, the production of this myth has taken on various forms, such as the declaration of the (originally Bahraini) eighteenth century pearling town Al Zubarah as a site of early Qatari state-formation, or the state-provision that all nationals are to wear 'national dress' as indicators of their status as Qatari citizens (Mitchell 2013; cooke 2015).

Over the last two decades, this narrative was developed and inspired primarily by Sheikh Hamad bin Khalifa Al Thani, Qatar's Emir from 1995-2013, and his visions to prominently place Qatar on the world map. In this context, different scholars point to Qatar's diplomatic skills and mediation efforts (Momani and Cooper 2001; Barakat 2012, 2014), the establishment of Al-Jazeera (Zayani 2005), the hosting of international sporting events (Dorsey 2015; Brannagan and Giulianotti 2014), the establishment of international elite universities and policy think tanks (Brewer et al. 2007; Lee 2015), and rapid and spectacular urban development (Koch 2014; Scharfenort 2012) as practices that have made the state noticed in international affairs.

A final practice that has recently received much scholarly attention are Qatar's investments into the cultural field. Before discussing how Doha has used culture to position itself internationally, however, it is important to note that most relevant projects in this field are closely tied to the rule of Sheikh Hamad and his 
internationalisation agenda (Exell 2016b; Kamrava 2013). In a region perhaps best characterised by constant change, state-agendas have shifted quite significantly over the course of the last few years. In June 2013, Sheikh Hamad handed over power to his son, Sheikh Tamim bin Hamad bin Khalifa Al Thani, and has since retreated into the background of Qatari politics under the title 'Father Emir'. Since 2013, Sheikh Tamim, who is generally considered to be more conservative and 'less heavy in intend' than his father (Hammond 2014, 5), has recalibrated much of Qatari politics, and called for economic austerity stressing that '[w]aste, extravagance, mishandling of state funds, [and] lack of respect for the budget... are all behaviours that must be disposed of, whether oil prices are high or low' (cited in Kovessy 2015).

In addition to the change in leadership, and a new, post-Arab Spring regional environment, Qatari politics has moreover been affected by the economic downturn. While we could previously hear statements such as '[we] do have all the resources to develop new cultural institutions ${ }^{3}$ from Doha, the last three to four years seem to have dampened its cultural ambitions. In 2016, QF's budget for international education initiatives was cut by 40\%, while QM downsized its staff number from 1200 to 800 , and saw the lay-off of a large number of expatriate workers (Ulrichsen 2016; World Bank 2016). The budget-cuts in the cultural sector also have to been seen as a calculated economic trade-off in favour of another fast-approaching expensive event: the 2022 FIFA World Cup. With only five years to go, large parts of Doha resemble 24-hour construction sites, where stadia, infrastructure and hotels are being built at an estimated cost surpassing US\$ 200 billion (Ulrichsen 2016). In this context, Adam (2016) has argued, '[f]ootball outsources culture as Qatar spending slumps', with '[e]verything else taking second place to this' $(1,4)$. 
Next to economic reasons, scholars and popular voices moreover argue that public opinion and local criticism against the Father Emir's out-ward looking agenda have pushed the government under Sheikh Tamim to de-emphasize the spending of large amounts of state-funds on emphasising Qatar's international profile (Hack 2014; Exel 2016a, 2016b). Criticism, for example, has been voiced against the acquisition of controversial art works such as Damien Hirst's 'The Miraculous Journey' (a series of fourteen statues depicting the gestation of a foetus inside a uterus), or Adel Abdessemed's 'Coup de Tete' (s statue of Zinedine Zidane at the 2006 World Cup) - the former having been veiled over, and the latter being taken away from the Corniche after a storm of local complaints (Exell 2016a). Assessing the content and weight of public opinion in Qatar is, however, a difficult task as the country is generally considered to be 'not-free', with restrictions on free speech and government criticism (Freedom House 2016). While a fascinating research topic in itself, the public reception of Qatar's cultural diplomacy is not a major part of the current analysis, which in accordance with the present research puzzle primarily focuses on government initiatives. Beyond this paper, however, the question of popular reception calls for much future research in order to enhance our understanding of the cultural field in Qatar.

\section{Cultural Diplomacy:}

In the context of Qatar as well as on a global scale, cultural diplomacy has recently attracted much scholarly attention as a political practice to attract global attention and display a unique national profile (Melissen 2005; Ang, Isar and Mar 2015; Hurn 2016). According to Mark (2009), cultural diplomacy is

'the deployment of a state's culture in support of its foreign policy goals or diplomacy, [and] is frequently seen as a subset of the practice of public diplomacy, a government's communication with foreign audiences in order to positively influence them' (4).

Another widely used definition of cultural diplomacy is Cummings' (2003), who understands it as 
'the exchange of ideas, information, art and other aspects of culture among nations and their peoples in order to foster mutual understanding which can also be more of a oneway street than a two-way exchange, as when one nation concentrates its efforts on promoting the national language, explaining its policies and point of view, or telling its story to the rest of the world' (1).

An important distinction between these definitions is that Mark clearly identifies a state government as the primary agent of cultural diplomacy, while Cummings uses the blurrier concept of 'nations and their people'. This paper builds on Mark and his emphasis on the government, as I am most interested in understanding how cultural diplomacy is used as a strategic policy tool by Qatar's political leadership. This difference in definition mirrors the often evoked distinction between 'cultural diplomacy' and 'cultural relations', the latter referring to the 'relations between national cultures [that] grow naturally and organically, without government intervention', and the former referring to activities carried out by agents 'serving national governments, try[ing] to shape and channel this natural flow to advance national interests' (Arndt 2005, xviii).

Mark and Cummings' definitions moreover underline the potential breadth of activities captured by the term 'cultural diplomacy'. What exactly does it mean if a government is promoting a state's culture; and what kind of practices should we focus on to study it? According to Fox (1999), much of the difficulty to define what cultural diplomacy is lies in the 'semantic baggage' of the term 'culture' (2). An 'essentially contested term' in the literature, in the context of 'cultural' diplomacy it has traditionally been used to refer to practices of 'high culture', such as the visual arts, literature, or classical music, all cultural expressions that have traditionally been the preserve of an intellectual elite (Gallie 1956; Mark 2009). In recent years, however, this interpretation has changed, as cultural diplomacy is now frequently considered to target a wider audience and to include activities such as educational exchanges, sport events, museums, trade fairs or food festivals (see Finn 2003; Ndlovu 2010; Ang, Isar and Mar 
2015; Hurn 2016). In the analysis below, I specifically look at Qatar's use of educational exchange programs, and initiatives of bilateral cultural cooperation, which have so far received only little attention in the academic discourse.

The occasion that first incited international interest in Doha's cultural scene, however, was the opening of QM's 'Museum of Islamic Art' (MIA) in November 2008. Writing at the time, Financial Times journalist Georgina Adam refers to 'sleepy but colossally rich little Doha [that] stole the show... with the opening of the truly splendid Museum of Islamic Art'. New York Times architecture critic Nicolai Ourousseff (2008) moreover called the museum 'the centerpiece of an enormous effort to transform Qatar into an arts destination' with 'one of the world's most encyclopaedic collections of Islamic art' [sic]. From an academic perspective, Exell and Wakefield (2016) call the opening of the museum 'a masterstroke of cultural diplomacy' at a 'time of deep distrust between the west and the Islamic world' (1). As particularly stated by QM's chairwoman Sheikha Mayassa bint Hamad bin Khalifa Al Thani, with the museum 'we want to show that Islam is a peaceful civilization, which has always called for tolerance and coexistence amongst different peoples' (Al Arabiya 2008). Speaking to an international audience and featuring a collection of artefacts from all over the world (but from Qatar) the MIA is considered to be the first major project to place Doha on the international cultural map, and project Qatar's self-image as a bridge between East and West, Islam and modernity (Ourousseff 2010; Levitt 2015).

Since the opening of the MIA, Qatar's cultural ambitions have become a frequent topic in (Western) international media (see New York Times 2009; The Economist 2012). The majority of observers speak about Qatar's art scene with a mixture of surprise, amazement and scepticism, with some very critical voices such as James Panero's 'The Widening Gulf' (2013), who calls Qatar's art initiatives a 'cover 
for further repressive politics', as 'visions of abstract thought [evolve] into symbols of autocratic power' $(39 ; 42)$. In parallel, there has been growing academic interest, focusing on the role of cultural display for state and nation-building (Fromherz 2012; Kamrava 2013), the special function of museums and their local collecting and displaying practices (Erskine-Loftus, Penzinger Hightower and Al-Mulla 2016; Exell 2016a, 2016b; Levitt 2015; Al-Mulla 2016), the construction of cultural heritage and tradition (Exell and Rico 2013, cooke 2015), the reform and internationalisation of the education sector (Alkhater 2016; Lee 2015), as well as the architecture of educational and cultural spaces (Al Raouf 2010, 2016; Koch 2014; Scharfenort 2016). This literature is quickly growing and expanding, with most scholars arguing that investments into the cultural sector have become an important political tool for both international positioning and/or the consolidation of national identity. Before moving on to the analysis, it is worth looking at this dual emphasis in some more detail.

\section{Cultural Diplomacy as 'Virtual Enlargement'}

Small states have long been considered as unlikely to become powerful actors in the international system given their relative lack of material power resources (population, territory, economy and military), often coupled with a position of geopolitical remoteness and invisibility (Vital 1967; Cooper and Shaw 2009). In the context of globalisation and the emergence of new forms of international connectivity, however, the relationship between size, power and influence is crumbling, as critical observers start to point to a range of alternate tools and practices open to small and otherwise marginalised states to re-define their global footprint (van Ham 2001; Nye 2004; Neumann and de Carvalho 2015). One such tool has been identified by Alan Chong (2010) as 'virtual enlargement' (365), that is, the potential for small states to enlarge their 'importance to' and 'presence in' the international community by drawing on 
alternative power resources, such as the building up of a foreign policy niche, diplomatic engagements, or the promotion of their culture (385f; Chong 2009). Importantly, Chong (2010) understands virtual enlargement as directly related to the small state's quest for security and survival. Rather than purely symbolic acts, practices of virtual enlargement should be interpreted as linked to the government's interests to secure its position in the international system.

In the context of this paper, Qatar's cultural diplomacy initiatives can be seen as practices of 'virtual enlargement', with Doha 'signalling to its neighbours and the world that it has arrived' (Levitt 2015, 91), that it is more than just an oil and gas state, and that it is ready to take on the role of a 'regional power [] with a truly international reach' (Ulrichsen 2012, 2). By forming bilateral partnerships, or organising international exchange programs, Doha can spread and virtually enlarge awareness about itself on a global scale. According to Roberts (2012), Qatar's cultural projects thus need to be seen as part of Doha's insurance policy to make sure that the world knows about Qatar, 'for not only is anonymity a bad quality to have should something go catastrophically wrong as it did for Kuwait in 1990', but also to give Qatar a 'competitive [economic] edge against its neighbours' (239). Often thought of as being in direct competition with Dubai and Abu Dhabi over foreign investment and tourists, the developments in Qatar's cultural sphere have become an important tool to differentiate Qatar from its neighbours, and to underline its competitive edge in a small, highly competitive region. In this context, Fromherz (2012) argues:

'What the [Father] Emir and his wife, Sheikha Mozah, seem to have grasped is that ideas, creativity and intellectual innovation are the greatest untapped resource in the Modern Middle East - this positioning of Qatar as a forum of independent thought in the Middle East, and not simply for material profit as in the Dubai model, is not, of course simply a selfless act done out of spontaneous benevolence and an idealist belief in the freedom of speech. There is perhaps no better way to subtly tune the ideas that that will determine the future of the Arab and Islamic world than to show the stage upon which those ideas are expressed. In this sense... Qatar has a voice regionally and internationally much larger than its size' (24). 
The usefulness of cultural diplomacy as a tool to enlarge and positively influence Qatar's image abroad has moreover been identified in the government's two key strategic documents: the 'Qatar National Vision 2030' (QNV) published in 2008 by the General Secretariat for Development and Planning (GSDP), and the 'Qatar National Development Strategy 2011-2016' (QNDS) published by GSDP in 2011. The former calls for a deepening 'cultural exchange with the Arab peoples in particular and with other nations in general' to reflect Qatar's role as a 'responsible member of the international community' with an 'important and constructive regional role' (GSDPa, 20). As a more detailed roadmap, the QNDS states that

\begin{abstract}
'Across the country, different agencies, including grassroots and community-based groups, are promoting Qatari culture, as well as foreign cultures, encouraging cultural exchange and intercultural dialogue. This outreach has enables Qatar to raise its sphere of influence worldwide. But to maximise impact, these various activities need to be enhanced, integrated and promoted within a national framework...for building national pride and encouraging intercultural understanding' (GSDPb, 205).
\end{abstract}

This point has moreover been emphasized by Qatar's former Minister of Culture Dr.

Hamad bin Abdulaziz Al Kuwari. Asked in an interview in 2015 how and why Qatar pursues international cultural partnerships, Al Kuwari answered

'Ever since the creation of the Ministry [of Culture] back in 2008, we have actively sought international contacts to build our network. The emphasis on culture in Qatar is now being recognized all over the world and great artists are coming here to exhibit their works...This is all part of the national strategy to strengthen our tourism industry and turn Qatar into a cultural center in the Gulf...we also believe that these cultural ties with other nations can pave the way for more stable political relations. Being a former diplomat, I can confirm that these cultural partnerships help in strengthening mutual beneficial and peaceful international relations' [sic] (Al Kuwari 2015).

These points reflect one major dimension of cultural diplomacy in Qatar: the drive to enlarge Qatar's international reach, to create international distinction and visibility, and to favourably position the state in global economic and political networks. Next to this outward-looking dimensions, there is, however, another, more inward-looking dimension, briefly discussed in the next section.

\title{
Cultural Diplomacy as the Shaping of National Identity
}


'And lest we forget', Roberts (2012) has argued in a recent article on Qatar's foreign policy, 'all politics is domestic' (329). This attitude is reflected in the QNV, which positions Qatar 'at a crossroads', facing both 'previously undreamt opportunities' as well as 'formidable challenges' (GSDPa, 1). As a major challenge, the QNV identifies the 'preservation of cultural traditions...in a rapidly globalizing and increasingly interconnected world', in which 'rapid economic change and population growth have created intense strains between the old and the new' (4). In other words, while Qatar is benefitting from economic and political globalisation, it also has to safeguard and protect its cultural heritage and national identity.

In the existing literature, the domestic implications of Qatar's global cultural ambitions have primarily been discussed in relation to its various museum projects (see Exell 2016a, 2016b and Levitt 2015), but remain largely unexplored in other settings. Beyond Qatar, the link between the outward projection of cultural policies and the shaping of national identity has, for example, been usefully explored by Valaskivi (2013) and Iwabuchi (2015) in the context of Japan. Valaskivi (2013) argues that the constant re-articulation of an image to the outside world becomes 'a way of seeking a common goal for the national project, a way of affirming certain values and shunning others' (2013, 490). Similarly, Iwabuchi (2015) argues that government strategies to communicate Japan's identity to the outside world have led to an 'uncritical reinforcement of a homogenized and exclusive understanding of national culture', which is 'not only directed externally, but also internally, as a tool for inculcating a narrative of the nation and a sense of belonging' (420, 427).

In the case of Qatar, the importance of this dynamic is exacerbated in the context of fast socio-economic change in which 'being Qatari' is on the one hand associated with economic and social privilege, while the presence of a large, non-national majority 
has on the other hand left Qataris to feel like 'strangers in their own land' (Exell 2016b; Ritzer 2015). 'Because the line between Qataris and non-Qataris is so salient', Livett (2015) argues, 'the internal differences within the Qatari category -with respect to tribe, denomination, or descent- are downplayed in official policies and discourses' (123). A central implication of this is the consolidation of a simplified national identity narrative that glosses over internal ethnic or religious strife, and ties the development of the state to the vision and leadership of the ruling elite (Fromherz 2012; Livett 2015; cooke 2015).

\section{Qatar Foundation and the WISE Initiative:}

One of the major players in Qatar's cultural landscape is the Qatar Foundation for Education, Science and Community Development (QF). Founded in 1995 by the Father Emir and his wife Sheikha Mozah bint Nasser Al Missned, QF's mission has been defined as supporting Qatar on its journey to become a knowledge-based economy (QF 2015). With the aim of transforming Qatar into a regional education hub, QF's flagship project is a campus-like development called 'Education City' that houses branch campuses of eight leading international universities. In official state discourse, Education City is simultaneously presented as a local initiative that gives local students the chance to get a world-class education without having to leave Qatar, and as a global initiative that underlines Qatar's commitment to international education excellence. A memo published on the occasion of QF's $20^{\text {th }}$ anniversary states that

'Instrumental in building a prosperous Qatar, QF's dedication to change and its leadership in actualizing this change, extends globally. QF is at the international vanguard of ensuring a better world for all by enabling and driving improvements in areas of paramount importance' (QF 2016b).

Looking at QF's international engagement, two initiatives stand out in particular. First, in 2007, QF established a subsidiary organisation based in the US called 'Qatar Foundation International' (QFI). According to QFI's mission statement, it is 'dedicated 
to connecting cultures and advancing global citizenship through education' (QFI 2016a). QFI's main initiative is the promotion of the Arabic language in the US, Canada, Great Britain and Brazil through its 'Arabic Schools' and 'Arabic Language and Culture' programs that started in 2009. By engaging other countries' youth, QFI 'aims to inspire connections with the Arab world and advance global citizenship by creating a global community of active, engaged and collaborative learners and educators' (QFI 2016b). A specific project is the introduction of Arabic classes into American mainstream education at the elementary, middle and high school level. Currently, QFI supports 20 schools in 10 American states, reaching over 2400 students (QFI 2016b).

On the QFI website, Qatar's Emir Sheikh Tamim is quoted to have said that 'Arabic language education is key, when you learn the language, you learn about the culture. We are happy to support language education. Anything we can do to add and help American people who want to learn Arabic we are happy to help' (QFI 2016b). QFI's work thus seems to resemble a one-sided focus on spreading the Arabic language and culture as a means to familiarize a primarily Western audience with the Arab world in general, and Qatar in particular. In the end, QFI's initiatives are best summarized as an attempt by QF, and by extension the Qatari government, to show its largesse to the world, and to increase its recognition and influence among strategic foreign audiences.

A second global education initiative pursued by QF is the 'World Innovation Summit for Education' (WISE). Since its inauguration in 2009, WISE has been growing in international influence and prestige. According to QF, WISE stands for a unique, global, action-oriented, multi-sectoral approach to education $(2013 \mathrm{~b}, 2)$ that is becoming a 'galvanizing force' and 'a beacon of inspiration' to ensure that 'a new world of education can be reached' (QF 2015). On its path to 'build the future of 
education through innovation and collaboration', the initiative has been holding an annual summit between 2009 and 2015, and engages in a range of year-round programs (QF 2013b).

The last WISE summit held in Doha in November 2015 was attended by a number of high-profile guests. A special address was given by Michelle Obama, who recognized Sheikha Mozah's 'outstanding work on behalf of women and children in Qatar' and expressed excitement to cooperate with Her Highness and WISE's 'Education Above All Foundation' to 'build a global movement that contributes to human, social and economic development through the provision of quality education' (The White House 2015; Education Above All 2016). At every summit, WISE moreover recognizes six 'cutting-edge projects' that contribute to the transformation of society and education globally through the WISE Award. According to WISE CEO Stavros Yiannouka, 'WISE Awards bring enhanced visibility to action-oriented projects that have had a demonstrated impact in their communities and can set the standard for similar initiatives worldwide' (QF 2016a, 2). Next to enhancing visibility of the projects, however, the WISE Award also serves to enhance the global visibility of Qatar, as it attracts the gaze of the international community, and projects a positive image of the state as positioned on the forefront of international education initiatives.

Similar to QFI's projects, WISE is constantly discussed with reference to Sheikha Mozah and her visionary leadership, thus constantly re-stating her role as one of Qatar's cultural patrons. The final report of the 2013 summit, for example, underlines that 'WISE began in 2009 in response to the conviction of...Her Highness Sheikha Moza...that access to relevant high-quality education is essential...for the challenges of an uncertain future' (QF 2013a, 4). As Qatar starts to reach a growing international 
audience, Qatar's message is repeatedly constructed as having originated in the minds of its progressive, innovative, and future-oriented elite.

What this short synopsis of QF's initiatives shows is that the promotion of global education in Qatar is a largely one-directional, unilateral and elite-driven practice. It is based on giving out awards, charity work, and the hosting of summits and conferences, rather than on a sustained effort of mutual cooperation between the Qatari people and foreign audiences. While there is some exchange in the sense that different dignitaries are invited to come to Qatar - these visits are used to showcase an atmosphere of cultural openness in a region stereotypically regarded as backwards, rather than to encourage visitors to leave their mark on the country and inspire sustained exchange. As such, QF's global investments in education form part of the leadership's plan to put Doha on the international map as a world-class hub for education, and to fashion Qatar as an advocate of social and economic development, philanthropy, crosscultural dialogue, partial political liberalization and women's rights. This narrative reflects what Levitt (2015) has called Doha's selective engagement with cosmopolitanism, in which cultural projects push the boundaries of thought, while Qatar otherwise remains 'not known for [its] respect for human rights or democracy' (130).

At the time of writing, we can observe some recent changes in the focus and scope of QF's international initiatives. The most visible change is the down-scaling of the WISE summit from an annual to a biannual event, with the next summit scheduled to take place in Doha in November 2017. According to an official statement by Yiannouka, the change to a biannual cycle is 'to allow more time and resources to be devoted to pursuing our global and local research and outreach agenda' (Gulf Times 2017). From a more critical perspective, however, the down-scaling of the high-class event rather seems to reflect recent budget-cuts. Another change at QF and Education 
City is that in 2013, the foreign universities officially became part of the local Hamad bin Khalifa Univeristy (HBKU) (Exell, 2016b), potentially signalling a move towards a more in-ward looking, home-focused development of the higher education sector. Despite these changes, QF's official narrative continues to underline the organisation's global reach and ambitions. In one of its latest monthly magazines, QF's vice CEO Sheikha Hind bint Hamad Al Thani recent visit to the US was called an opportunity to 'strengthen international ties in the field of education...encourage knowledge sharing, and promoted intercultural exchange' (QF 2017, 1).

\section{Qatar Museums and the 'Years of Culture':}

QM is the second major governmental institution that is involved in spreading Qatar's cultural message to the world. It was founded by the Father Emir in 2005, and has subsequently been led by Sheikha Mayassa with the vision to develop an effective system for collecting, protecting and preserving Qatar's cultural heritage and identity.

Over time, the organisation's scope of activities widened, as Qatar's leadership expressed ambitions to transform Doha into a world class 'cultural hub'. Today, the organisation presents itself a cultural instigator that invests into the people of Qatar to help fulfil the cultural goal of the QNV. In order to deliver this ambition, it is portrayed as paramount that Qatar develops a unique cultural identity, and that it promotes its own distinctive place within global debates on culture and creativity. In the words of Sheikha Mayassa 'We don't want to be the same...We want to build our own identity, our own fabric' (QM 2016a).

Next to QM's various museums as the primary sites of Qatar's cultural development (most importantly the MIA and Mathaf: Arab Museum of Modern Art), QM has over the last years engaged in a number of targeted initiatives to strengthen Qatar's (inter)national cultural profile, such as the Fire Station Artist in Residence 
Program that brings together local and international artists in Qatar (QM 2017c). One recent practice that stands out as QM's most concerted effort of international cultural cooperation, is the 'Years of Culture' (YoC) Initiative inaugurated in 2012 by QM's Office of Strategic Cultural Relations (Ghose 2013). Operating under the motto 'Years of Culture - Building Bridges between Nations' (2016b), the YoC are 'designed to take Qatar to the world, and bring the world to Qatar', and promoted as a 'landmark initiative to deepen understanding between nation and their people through mutual exchange of arts, culture, heritage and sports' (QM 2015a). Since 2012, QM has partnered with Japan (2012), the United Kingdom (2013), Brazil (2014), Turkey (2015), China (2016), and Germany (2017), and is planning to set up partnerships with Russia (2018), India (2019), France (2020) and the United States (2021).

While the decision-making process behind the selection of partnering countries remains in-transparent, it nevertheless suggests a calculated political strategy. First, the selection of Brazil and Russia overlaps with the years that these states are hosting the FIFA World Cup. Given Qatar's successful bid to the host the event in 2022, the timing of the YoC for 2014 and 2018 speak to Qatar's strategy to enlarge its international profile through investments in the professional sporting sector. Second, all of these countries are states that Qatar enjoys close economic and political ties with. It was the Japanese government, for example, that in the late 1990s invested heavily in the development of Qatar's Liquefied Natural Gas (LNG) industry, and thus considerably contributed to Qatar's fast-paced economic development. 2012 was also the year in which Qatar announced the establishment of a US\$ 100 million 'Qatar Friendship Fund' to support Japan after it was hit by a devastating earthquake in 2011. The UK and Qatar, moreover share a special bond due to the latter's status as a former UK protectorate. Until today, relations between Qatar and the UK remain close, with many members of 
the Qatari royal family being educated at British universities, and a high frequency in diplomatic visits between the two states. Qatar's relationship with Turkey, has increasingly gotten closer over the last years, with Sheikh Tamim and President Erdogan signing a number of economic and political cooperation agreements, including the decision to establish a Turkish military base in Qatar (Walker 2015). China, moreover, has over the last years emerged as one of Qatar's most important economic partners. After the signing of a number of bilateral trade deals in 2011, Qatar is now the largest exporter of LNG to China, meeting $20 \%$ of its domestic energy needs. Similarly important for Qatar's economic development are its historically close ties to India. While Qatar's official currency was the Indian Rupee until the 1950s, today approximately 631,000 Indian migrant workers are working in Qatar, a number that continues to rise (Al Ziyara 2014).

Ongoing and planned cooperation with Germany, France and the US are also within Qatar's economic and political interests. In 2014, the trade volume between Germany and Qatar reached US\$ 2 billion, with many German companies working in Qatar's booming infrastructure sector, and a growing number of Qataris travelling to Germany each year for tourism or medical procedures. France, moreover, has traditionally been an important player in the region, and relations with Qatar have grown increasingly close over military cooperation and Qatari investments in France, such as the purchase of the Paris St. Germain football club in 2011. Of all Western states, however, the US remains Qatar's most important partner. Following 9/11, the headquarter of US Central Command was relocated from Saudi Arabia to Qatar, and for the last fifteen years, Qatar has hosted the largest number of American soldiers outside the US. Overall, the states Qatar decides to cooperate with in the cultural sphere are no strangers to its Ministry of Foreign Affairs. In this context, cultural diplomacy has 
developed into a strategic tool to deepen existing relationships, and clothe the enhancement of national interests in the mantle of cultural cooperation.

A close reading of official communications moreover shows that officials at QM use the $\mathrm{YoC}$ as a platform to disseminate an elite identity narrative of Qatar as a 'cultural hub' that is 'ambitious', 'innovative', 'cooperative' and 'significant'. While the $\mathrm{YoC}$ encompass a multitude of events that indeed are inspired by the cultures of the partnering states, these events are mainly high-profile activities that are used by QM to project Qatar's rising international prestige and leading role in international cultural circles. Over the last years, QM has brought world-renowned painters, film-makers, musicians and scientists to Doha, thereby underlining Qatar's pioneering role as the first and only Middle Eastern state to stage the largest and most controversial cultural exhibitions. Partnering primarily with world-renowned institutions and individuals and sparing no opportunity to underline this, Qatar's cultural diplomacy initiatives primarily seem to serve as photo opportunities, reasons to issue press releases, and adding big names to legacy lists. All in all, while the YoC are officially portrayed as an engine to encourage cross-cultural understanding and cooperation, they are mainly aiming at increasing cultural traffic within Doha itself. As Dr. Khalid bin Ibrahim Al Sulaiti, General Manager of the Katara Cultural Village noted while working on Qatar-UK 2013

'[Qatar] aims to host events and cultural festivals of different countries, based on the firm belief to make Qatar a beacon of global thought, culture and convergence - a starting point for all kinds of arts and creativity and an area for communication and openness' (Gulf Times 2013).

What is further indicative of $\mathrm{YoC}$ as a means to attract global attention is that QM refers to all partnering states in largely the same rhetoric, underlining notions of friendship, long-lasting relations, and future potentials. Setting out to 'invite the world to Doha, and bring Qatar's heritage to the world', the international audience of the YoC remains 
rhetorically open, with more emphasis put on Qatar itself and the message it wants to share. A comment made by Safiya Al Hajari, QM's Director for Strategic Cultural Relations, summarizes this point

'The Years of Culture initiative reflects upon and displays Qatar's past, present and future by creating and interpreting culture through art. It brings world cultures to Qatar and takes our heritage, art and traditions to the world' (QM 2016b).

If we further focus on the question what aspects of Qatari culture the YoC put on display, it becomes evident that the initiative also serves as a means of (re)-enforcing a top-down domestic identity narrative. Creating a dichotomy of 'us' versus 'them', the YoC pose a simplified interpretation of Qatari identity against a changing global 'other'. As QM CEO Mansour bin Ebrahim Al Mamoud notes, 'the Years of Culture made the world take a closer look at Qatar, acknowledge our ancient civilization and understand reasons behind our swift cultural renaissance' $(2015,6)$. 'Cultural renaissance' here means that even in times of rapid modernisation, Qatar is remembering and embracing its cultural roots, eager to stress that its 'history as a nation goes back centuries before the discovery of oil and gas' (QM 2016c). The outcome is an often self-stereotyping, idealised image of Qatar somewhere between 'the vibrant cityscapes of Doha and the shifting sands of the Qatari desert', and an idealised image of Qataris as united by their love for kahwa, Arabic calligraphy and traditional sword dances (Gulf Times 2015; QM 2015a).

One example of the portrayal of Qatari culture is the exhibition 'Pearls - Jewels from the Sea' that QM has sent to Japan, the UK, Brazil, and Turkey. While not all pearls come from Qatar, QM uses this exhibition to offer visitors a 'unique glimpse into Qatar's past', exploring the 'pearl-fishing trade in the Arabian Gulf and the trading practices of the region's pearl merchants' (QM 2015b). According to QM,

'Qatar was at the heart of the pearl trade for over 7,000 years. The story of pearls and pearl fishing remains fundamental to Qatar's history as a nation, shedding light on a heritage that goes back centuries...the exhibition demonstrated Qatar's role in bringing 
the world this natural gem, and helps an international audience better understand us' (2016c).

As sources of national identification, these instances of cultural diplomacy paint an idealised, tourist-friendly image of the state that only scratches the surface of its identity in flux. As stated in the QNV, one of the biggest challenges Qatar is facing is the erosion of its national identity, as globalisation is speeding up and Qatar's engagement with the outside world deepens. This is the foreign policy course that came to characterize Qatar under the Father Emir, and now, as the Qataris themselves have become a small minority in their own country, the YoC provide a platform to not only 'celebrate Qatar's relations with the outside world', but also to remind locals of their own identity. It remains questionable, however, how deep these displays run to actually describing Qatar, its history, people and culture. As such, the YoC resemble a topdown, unilateral tool used by the Qatari elite to reinforce an idealized sense of national identity, while simultaneously seeking international attention as a progressive and modern state that can successfully host big, high-profile events. This is the image Qatari elites want to project outward, thus building up a niche identity to impede the issue of international invisibility. At the same time, the projection of this outward image is used to instigate compliance domestically, effectively telling the local population 'this is how we want the world to know us, so this is how we will have to be'. Importantly, there is nothing essential about this construction of national identity. Quite the contrary, it is the result of a concerted construction effort by Qatari elites, at the heart of which is the Al Thani development vision.

Looking ahead, the the YoC initiative is ongoing despite the budget cuts. This year's Qatar-Germany partnership opened with a concert by the Qatar Philharmonic Orchestra in February 2017, and 'more than a dozen events' have been announced for the remainder of the year (QNA 2017). While this number sounds more modest than the 
over 30 events held in 2012 (Qatar-Japan), or the 90 in 2013 (Qatar-UK), there are a number of other big QM projects planned for completion over the next few years, most importantly the new National Museum of Qatar, the Oriental Museum, and the Qatar Olympic and Sports Museum (QM 2015a; QM 2017a). In order to assess the sustained impact of economic re-scaling on Qatar's cultural sector, it will be necessary to observe how these projects unfold. For now, they have all been integrated into the official state discourse. The new National Museum, for example, is generally presented as a place that 'will give voice to Qatar's heritage whilst celebrating its future' (QM 2017b), in other words, a place to remind Qataris of who they are, and the world of its growing cultural significance.

\section{Conclusion:}

This paper has considered how the government of Qatar has over the last years used practices of cultural diplomacy to 'virtually enlarge' its presence abroad, and spread a unifying national identity narrative at home. To support this argument, the first part of the paper reflected on cultural diplomacy as a suitable policy tool in the context of Doha's external insecurities and its particular socio-economic internal make-up. The second part then provided a detailed analysis of key initiatives of international cultural collaboration of the state's two main cultural organisations. In this context, I argued that initiatives such as WISE or the Years of Culture should on the one hand be seen as strategies of virtual enlargement that demand recognition and inclusion for the Qatari state into a circle of key global influencers. On the other hand, these practices simultaneously create and (re)produce an elite identity narrative that paints an idealised image of a coherent and progressive Qatari nation that is simultaneously weary of its past while looking firmly into the future. By continuously being presented as guided by the 'wise leadership' of the ruling family, these practices of cultural diplomacy 
moreover validate the state-centric narrative behind them, and become symbolic performances to consolidate and legitimate Al Thani rule on the Qatari peninsula.

As a timely contribution, the analysis moreover shows that while the current economic downturn has led to the re-scaling of some of Doha's cultural initiatives, it has not yet resulted in major shifts in official state narratives about Qatar's national vision and global ambitions. With another international education summit coming up, a number of museums to be opened over the course of the next years, and the Football World Cup approaching quickly, Qatar and its cultural sector hence remain a topic well worth observing. 


\section{References:}

Adam, Georgina. 2008. "Fireworks as Qatar Steals the Show." Financial Times. http://www.ft.com/cms/s/0/32689cbe-bdb8-11dd-bba1$0000779 \mathrm{fd} 18 \mathrm{c} . \mathrm{htm} l \mathrm{ft} \_$site=falcon\&desktop=true\#axzz4W6tWCCl0.

Adam, Georgina. 2016. "Football Outscores Culture as Qatar Spending Slumps Museum Layoffs and Project Suspensions Gather Pace in Qatar as Oil Revenue." The Art Newspaper. http://theartnewspaper.com/news/museums/football-outscoresculture-as-qatar-spending-slumps/.

Al Kuwari, Nasser. 2015. "Cultural Gem.” The Business Year. https://www.thebusinessyear.com/qatar-2015/cultural-gem/interview.

Alkhater, Lolwa R.M. 2016. "Qatar's Borrowed K-12 Education Reform in Context." In Policy-Making in a Transformative State - The Case of Qatar, edited by M. Evren Tok, Lolwa R.M. Alkhater, and Leslie A. Pal, 97-130. London: Palgrave Macmillan.

Ang, Ien, Yudhishthir Raj Isar, and Phillip Mar. 2015. "Cultural Diplomacy: Beyond the National Interest?" International Journal of Cultural Policy 21 (4): 365-81. doi:10.1080/10286632.2015.1042474.

Brannagan, Paul Michael, and Richard Giulianotti. 2014. "Soft Power and Soft Disempowerment: Qatar, Global Sport and Football's 2022 World Cup Finals." Leisure Studies 34 (6): 703-19. doi:10.1080/02614367.2014.964291.

Brewer, Dominic J., Catherine H. Augustine, Gail L. Zellman, Gery Ryan, Charles A. Golfman, Cathleen Stasz, and Louay Constant. 2007. "Education for a New Era. Design and Implementation of K-12 Education Reform in Qatar.” Doha.

Carvalho, Benjamin De, Iver B Neumann, and Benjamin De Carvalho. 2015. "Introduction: Small States and Status." In Small State Status Seeking: Norway' S Quest for International Standing, edited by Iver B Neumann and Benjamin De Carvalho, 1-22. London and New York: Routledge.

Chong, Alan. 2009. "Singapore and the Soft Power Experience." In Diplomacies of Small States: Between Vulnerabilities and Resilience, edited by Andrew F. Cooper and Timothy M. Shaw, 65-80. Palgrave Macmillan.

Chong, Alan. 2010. "Small State Soft Power Strategies : Virtual Enlargement in the Cases of the Vatican City State and Singapore the Cases of the Vatican City State and Singapore." Cambridge Review of International Affairs 23 (3): 383-405. doi:10.1080/09557571.2010.484048.

CIA Factbook. 2016. "Country Comparison: Area." Central Intelligence Agency (CIA). https:/www.cia.gov/library/publications/the-worldfactbook/rankorder/2147rank.html\#qa. 
Cooper, Andrew F., and Timothy M. Shaw. 2009. Diplomacies of Small States: Between Vulnerability and Resilience. Palgrave Macmillan.

Cummings, Milton C. 2003. "Cultural Diplomacy and the United States Government." Washington, DC.

Dorsey, James M. 2015. "How Qatar Is Its Own Worst Enemy.” The International Journal of the History of Sport 32 (3): 422-39. doi:10.1080/09523367.2015.1008212.

Education Above All. 2016. "Unlocking Potential through Education.” Education Above All. http://educationaboveall.org/\#!/about/1.

Exell, Karen, and Sarina Wakefield. 2016. "Introduction - Paradigms of Practice in Arabian Museums." In Museums in Arabia: Transnational Practices and Regional Processes, edited by Karen Exell and Sarina Wakefield, 1-16. London: Routledge.

Exell, Karen, and Trinidad Rico. 2013. "There Is No Heritage in Qatar': Orientalism, Colonialism and Other Problematic Histories." World Archaeology 45 (4): 670-85. doi:10.1080/00438243.2013.852069.

Exell, Karen. 2016. "Desiring the Past and Reimagining the Present: Contemporary Collecting in Qatar." Museum \& Society 14 (2): 259-74.

Exell, Karen. 2016b. "Locating Qatar on the World Stage - Museums, Foreign Expertise and the Construction of Qatar's Contemporary Identity." In Representing the Nation: Heritage, Museums, National Narratives and Identity in the Arab Gulf States, edited by Pamela Erskine-Loftus, Victoria Penzinger Hightower, and Mariam Ibrahim Al-Mulla, 27-41. London: Routledge.

Finn, Helena K. 2003. "The Case for Cultural Diplomacy: Engaging Foreign Audiences." Foreign 82 (6): 15-20.

http://www.foreignaffairs.org/articles/59359/helena-k-finn/the-case-for-culturaldiplomacy-engaging-foreign-audiences.

Freedom House. 2016. "Qatar.” Freedom House Country Report. https://freedomhouse.org/report/freedom-world/2016/qatar.

Fromherz, Alan. 2012. Qatar: A Modern History. New York: IB Tauris.

Gallie, W. B. 1956. "Essentially Contested Concepts." Proceedings of the Aristotelian Society (Reprinted in Philosophy and the Historical Understanding). New York: Schocken Books.

General Secretariat for Development Planning (GSDPa). 2008. "Qatar National Vision 2030." Doha.

General Secretariat for Development Planning (GSDPb). 2011. "Qatar National Development Strategy 2011-2016.” Doha, Qatar. www.gsdp.gov.qa. 
Ghose, Sumantro. 2013. "Museums and Cultural Diplomacy Projects in Qatar and the Middle.” Berlin: Institute of Cultural Diplomacy Conference.

Gulf Times. 2013. "Scotland Day Festival Held at Katara Village." Gulf Times. http://www.gulf-times.com/story/371810/Scotland-Day-festival-held-at-KataraVillage.

Gulf Times. 2015. "Qatar-Turkey 2015 Launches Exhibition.” Gulf Times. http://www.gulf-times.com/story/453510/Qatar-Turkey-2015-launches-exhibition.

Gulf Times. 2017. "WISE Event Shifts to Biennial Cycle." Gulf Times. http://m.gulftimes.com/Story/494007.

Hack, Susan. 2017. "Qatar's Billion-Dollar Art Collection Causes Controversy." Bloomberg. https://www.bloomberg.com/news/articles/2014-10-02/qatar-s-billiondollar-art-collection-causes-controversy.

Hurn, Brian J. 2016. "The Role of Cultural Diplomacy in Nation Branding." Industrial and Commercial Trading 48 (2): 80-85.

Iwabuchi, Koichi. 2015. "Pop-Culture Diplomacy in Japan: Soft Power, Nation Branding and the Question of "international Cultural Exchange."' International Journal of Cultural Policy 21 (4): 419-32. doi:10.1080/10286632.2015.1042469.

Kamrava, Mehran. 2013. Qatar: Small State, Big Politics. New York: Cornell University Press.

Kluijver, Robert. 2013. "Contemporary Art in the Gulf: Context and Perspectives." The Gulf Art Guide.

http://www.sciencespo.fr/psia/sites/sciencespo.fr.psia/files/Contemporary Art in the Gulf for print.pdf.

Koch, Natalie. 2014. "“Building Glass Refrigerators in the Desert': Discourses of Urban Sustainability and Nation Building in Qatar." Urban Geography 35 (8): 1118-39. doi:10.1080/02723638.2014.952538.

Lee, Jack T. 2015. "Soft Power and Cultural Diplomacy: Emerging Education Hubs in Asia." Comparative Education 68 (June): 1-22. doi:10.1080/03050068.2015.1037551.

Mark, Simon. 2009. "A Greater Role for Cultural Diplomacy.” Discussion Paper Netherlands Institute of International Relations "Clingendeal," 1-51.

Melissen, Jan. 2005. Rethinking the "New" Public Diplomacy. Edited by Jan Melissen. The New Public Diplomacy - Soft Power in International Relations. New York: Palgrave Macmillan.

Ministry of Development Planning and Statistics. 2017. "Indicators." Ministry of Development Planning and Statistics.

http://www.mdps.gov.qa/en/pages/default.aspx. 
Mitchell, Jocelyn Sage. 2013. "Beyond Allocation: The Politics of Legitimacy in Qatar." Georgetown University.

http://www.qatar.northwestern.edu/docs/faculty/Mitchell-2013-Beyond-

Allocation-title-TOC.pdf.

Ndlovu, Sifiso Mxolisi. 2010. "Sports as Cultural Diplomacy: The 2010 FIFA World Cup in South Africa's Foreign Policy." Soccer \& Society 11 (1-2): 144-53. doi:10.1080/14660970903331466.

Nye, Joseph. 2004. The Changing Nature of Power. New York: Public Affairs.

Panero, James. 2013. “The Widening Gulf.” The New Criterion 35 (2): 39-47. http://www.newcriterion.com/articles.cfm/The-widening-Gulf-7762.

Peterson, J E. 2006. "Qatar and the World : Branding for a Micro-State.” Middle East Journal 60 (4).

Qatar Foundation International. 2016a. “About Us.” Qatar Foundation. http://qfi.org/about/\#mission.

Qatar Foundation International. 2016b. "Arabic Schools Program.” Qatar Foundation International. http://qfi.org/programs/arabic-language-and-culture/partnerschools/.

Qatar Foundation. 2013a. “Annual Report 2012-2013.” Doha.

Qatar Foundation. 2013b. "World Innovation Summit for Education - 2013, A Year in Review.” Doha, Qatar.

Qatar Foundation. 2015. "An Investment in Education.” The Foundation. http://www.qf.org.qa/content/the-foundation/issue-83/an-investment-in-education.

Qatar Foundation. 2016a. "Wise Awards 2016.” Doha, Qatar. http://www.wiseqatar.org/sites/default/files/2016_wise_awards_brochure.pdf.

Qatar Foundation. 2016b. "Rethinking and Reshaping Related News Education on a Global Scale." Qatar Foundation. http://www.qf.org.qa/content/20th/rethinkingand-reshaping-education-on-a-global-scale.

Qatar Foundation. 2017. "Her Excellency Sheikha Hind Bint Hamad Al Thani Puts Focus on Education and Innovation during US Visit." Qatar Foundation Telegraph, no. 180. http://www.qf.org.qa/explore/publications/qf-telegraph.

Qatar Museums. 2015a. Qatar Japan 2012 Year of Culture. Doha: Akkadia Press.

Qatar Museums. 2015b. Qatar UK 2013. Dubai and Doha: Akkadia Press.

Qatar Museums. 2016a. "Her Excellency Sheikha Al Mayassa Shaping Qatar' S Creative Future." Qatar Museums. http://www.qm.org.qa/en/her-excellencysheikha-al-mayassa. 
Qatar Museums. 2016b. "Years of Culture." Qatar Museums. http://www.qm.org.qa/en/years-culture.

Qatar Museums. 2016c. “Qatar-Brazil 2014.” Qatar Museums. http://www.qm.org.qa/en/qatar-brazil-2014.

Qatar Museums. 2017a. “Qatar-UK 2013.” Qatar Museums. http://www.qm.org.qa/en/qatar-uk-2013.

Qatar Museums. 2017b. "National Museum of Qatar.” Qatar Museums. http://www.qm.org.qa/en/project/national-museum-qatar.

Qatar Museums. 2017c. "Fire Station Artist in Residence - A Hub for Creative Exchange." Qatar Museums. http://www.qm.org.qa/en/fire-station-artist-residence.

Qatar News Agency (QNA). 2017. "Qatar Germany Year of Culture 2017 to Start Wednesday." Qatar News Agency. http://www.qna.org.qa/enus/News/17012916530036/Qatar-Germany-Year-of-Culture-2017-to-StartWednesday.

Reiche, Danyel. 2014. "Investing in Sporting Success as a Domestic and Foreign Policy Tool: The Case of Qatar." International Journal of Sport Policy and Politics 7 (4): 489-504. doi:10.1080/19406940.2014.966135.

Ritzer, George. 2015. "Globalization: Qataris, Strangers in Their Own Land.” In Introduction to Sociology, 2nded., 300-302. Los Angeles, London, New Delhi, Singapore, Washington DC: Sage.

Rivera, Tim. 2015. "Distinguishing Cultural Relations From Cultural Diplomacy: The British Council's Relationship With Her Majesty' S Government." https:/uscpublicdiplomacy.org/sites/uscpublicdiplomacy.org/files/useruploads/u33 041/Distinguishing Cultural Relations From Cultural Diplomacy - Full Version (1).pdf.

Scharfenort, Nadine. 2012. "Urban Development and Social Change in Qatar: The Qatar National Vision 2030 and the 2022 FIFA World Cup." Journal of Arabian Studies 2 (2): 209-30. doi:10.1080/21534764.2012.736204.

Scharfenort, Nadine. 2016. "The Msheireb Project in Doha: The Heritage of New Urban Design in Qatar." In Cultural Heritage in the Arabian Peninsula: Debates, Discourses, and Practices, edited by Karen Exell and Trinidad Rico, 189-204. Abingdon and New York: Routledge.

The Economist. 2006. "Qatar: A Bouncy Bantam.” The Economist, September 7. http://www.economist.com/node/7887812.

The Economist. 2011. "Pygmy with the Punch of a Giant." The Economist, November 5. http://www.economist.com/node/21536659. 
The Economist. 2012. "Qatar' S Culture Queen.” The Economist.

http://www.economist.com/node/21551443.

The White House. 2015. "Remarks by the First Lady at World Innovation Summit for Education on Let Girls Learn: Educating Adolescent Girls Worldwide." The White House. https://www.whitehouse.gov/the-press-office/2015/11/04/remarks-firstlady-world-innovation-summit-education-let-girls-learn.

Ulrichsen, Kristian Coates. 2012. "Qatar: Emergence of a Regional Power with International Reach.” E-Ir. http://www.e-ir.info/2012/01/23/qatar-emergence-of-aregional-power-with-international-reach/.

Ulrichsen, Kristian Coates. 2016. "Qatar: Reshuffling Toward Austerity." The Arab Gulf States Institute in Washington. http://www.agsiw.org/qatar-reshufflingtoward-austerity/\#more-5172.

Valaskivi, K. 2013. "A Brand New Future? Cool Japan and the Social Imaginary of the Branded Nation.” Japan Forum 25 (4): 1-19.

van Ham, Peter. 2001. "The Rise of the Brand State." Foreign Affairs. http://www.foreignaffairs.com/articles/57229/peter-van-ham/the-rise-of-the-brandstate.

Vital, David. 1967. The Inequality of States: A Study of the Small in International Relations. Oxford: Claredon Press.

Walker, Lesley. 2015. "Five Things to Know about the Turkish President' S Visit to Qatar." Doha News. http://dohanews.co/five-things-to-know-about-the-turkishpresidents-visit-to-qatar/.

Winckler, Onn. 2015. "How Many Qatari Nationals Are There?” Middle East Quarterly 2015: 1-16.

World Bank. 2016. "How Is Qatar Reacting to Low Oil Prices?” World Bank. http://www.worldbank.org/en/country/gcc/publication/economic-brief-july-qatar2016.

Zayani, Mohamed. 2005. The Al Jazeera Phenomenon. Edited by Mohamed Zayani. London and Boulder, CO: Pluto Press / Paradigm Publishers. 